\title{
Legal Analysis of the Role of Islamic Urban and Rural Councils in Administrative Decentralization and Local Democracy in Iran
}

\author{
Mohammad Zadeh Asl Mohammad ${ }^{1}$, Heibatollah Nazhandimanseh ${ }^{1,2}$, Manoochehr Tabatabei Motameni ${ }^{3}$, \\ Hoseein Masudniya ${ }^{4} \&$ Manoochehr Tavasoli Naini ${ }^{1}$ \\ ${ }^{1}$ Deparment of Law, Najafabad Branch, Islamic Azad University, Najafabad, Iran \\ ${ }^{2}$ Deparment of Law and Political Science, Alameh Tabatabei University, Iran \\ ${ }^{3}$ Department of Law and Political Science, Faculty of Law, University of Tehran, Iran \\ ${ }^{4}$ Deparment of Law and Political Science, University of Isfahan, Isfahan, Iran \\ Correspondence: Heibatollah Najandimanseh, Deparment of Law, Najafabad Branch, Islamic Azad University, \\ Najafabad, Iran. E-mail: Hnajandimanesh@gmail.com
}

\author{
Received: February 2, 2016 Accepted: August 11, 2016 Online Published: September 29, 2016 \\ doi:10.5539/jpl.v9n8p1 URL: http://dx.doi.org/10.5539/jpl.v9n8p1
}

\begin{abstract}
Administrative decentralization is one of the most marvelous achievements of public laws in current age. Obviously, based on the title of the book namely Islamic Councils, we mean a certain type of local decentralization is shaped by geographical areas. In modern administrative laws, decentralization is raised in two geographical and technical aspects. Local councils are objective sign of geographical decentralization and legal figures of public laws such as universities are instances of technical decentralization.

In this concept, decentralization is shaped by two concepts of "managerial independence" and "elective decision making authority". In modern administrative system, decentralization means to increase the authorities of elected officials whose proficiencies are assignable only in a region of the country. Before getting familiar with such great achievement, we should address the philosophy governing decentralization and its status in modern democracies.
\end{abstract}

Keywords: authority delegation, local councils, decentralization, local democracy

\section{Introduction}

Democracy is a kind of administration in which people play a vital role in monitoring the administration. In fact, citizens elect their representatives in a process called elections and they run citizens' affairs in the name of "nation" ( Bashirieh, 2008, 64). Obviously, such representativeness is granted only in political affairs or administrative/political nature. Therefore, in democracy, only one aspect of contribution namely political contribution is considered (Eivazi, 2006, 28). The main question is that whether democracy is fully realized by citizens' political contribution or not.

Islamic councils are divided into based and hegemonic councils. Each council has its own tasks and authorities in keeping citizens' social and cultural rights. These tasks can be divvied into general and special tasks .

General tasks of councils are also categorized in two groups:

Group 1: lawmaking by councils (urban, rural and provincial councils) which include local governance roles in controlling public activities and approving the laws on how to run local affairs for residents. Islamic councils are obliged to follow laws and approvals by central government. In other words, the approvals of Islamic councils should not be in contrary to current domestic laws and if there is such contradictory, central government is able to cancel them. Islamic councils have tasks to recognize deficiencies and needs of their location and they should approve laws to removes local needs and difficulties.

Group 2: it includes general functions of councils to provide public services. All Islamic councils are tasked to move toward a local people approach, to recognize their needs, to remove them and to grant public services.

\section{Councils and Their Roles}

Councils are organizations depended from ministries and are so-called "local organizations or local councils" in 
which local affairs and services are designated to residents in terms of administrative decentralization. In fact, these are domestic organs like village, parish, township and province run in decentralized manner. In past, these councils were called associations (Tabatabei Motameni, 2002, 100) .

Islamic councils are divided into based and hegemonic councils. Each council has its own tasks and authorities in keeping citizens' social and cultural rights. These tasks can be divvied into general and special tasks (Danesh Khsohbu, 1970).

General tasks of councils are also categorized in two groups:

Group 1: lawmaking by councils (urban, rural and provincial councils) which include local governance roles in controlling public activities and approving the laws on how to run local affairs for residents. Islamic councils are obliged to follow laws and approvals by central government. In other words, the approvals of Islamic councils should not be in contrary to current domestic laws and if there is such contradictory, central government is able to cancel them. Islamic councils have tasks to recognize deficiencies and needs of their location and they should approve laws to removes local needs and difficulties ( AlKajbaf, Hussein, 2008, 52) .

Group 2: it includes general functions of councils to provide public services. All Islamic councils are tasked to move toward a local people approach, to recognize their needs, to remove them and to grant public services ( Ibid, 56) .

As a national covenant, I. R. of Iran Constitution Law is considered as the most important and endurable achievement of Islamic revolution that acquired its credit and legitimacy by the votes and majority of Iranian population. To this end, any initiative, decision or action of regime's pillars is emanated from prescriptions and competencies considered by the Constitution Law or recognized if not in contradictory to Constitution Law. The background of councils backs to pre-Islamic revolution and is not a new and contemporary phenomenon; rather the phenomenon of councils has a background of 1400 years in Islam and Holy Lawmaker has emphasized it in Holy Quran especially two verses (Zahedi, 2006, 32). Despite of this, in a few Islamic societies, this valuable principle is respected and acted by rulers and they have often ignored using collective wisdom in running the affairs and decision making and they considered no virtue for people (grassroots) to utilize them in their decision making. In the case that some rulers attempted to consult with others, they were in the level of necessity and feeling in a special time and condition under which people's votes should be considered while the words of the Divinity to Prophet Mohammad (PBUH) in Holy Quran was not a forma one and its seems that to operationalize council phenomenon and real consultancy was considered by Islamic Lawmaker (Ibid , 46)since if it was not the case, never the Divinity told in Holy Quran (Rightly, no nation changes otherwise it changes its conditions and society willfully). Therefore, it is impossible to study changes on the conditions of people in a society without their contribution in determining the fate of their country and in decision making processes so that Imam Khomeini (PBUH) asserted "majority would not commit a mistake" or "30 million people doe make a mistake". It does not mean that the majority should stay in their homes and have no role in their own fate, society and country. However, they should not make a mistake. Not making a mistake or the assumption of making a mistake is meaningful where people contribute in the fate of their decision makings and in fact people experience how to run a society and then the collective wisdom and the opinion of majority would not make a mistake. If today chapter of the Constitution Law with seven principle as well as principles 6 and 7 are allocated to councils, in fact law makers and Imam Khomeini paved the way for people's contribution in decision making arenas by adopting such legal and practical mechanisms so it seems that it is more than advices emanated from needs of rulers in special conditions since after Islamic Revolution, the phenomenon of council and consultancy changed from theory to practice legally and council organ was seen as a pillar of the regime. The Constitution Law indicates that these are people who enforce council organs like Parliament, rulers and agents to act and execute decisions in the framework of adopted norms and regulations ( Khatami, 2009, 39) .

Another point is that councils and council system has special status in pre-Islam communities such as Greece in the age of Aristotle and Plato to run the cities so that in Greece, people played more roles than common consultancies considered in I. R. of Iran. Among three regimes of kingdom, aristocracy and democracy (Politeia), Aristotle preferred democracy to other two regimes ( Frederic, 2010, 61). Although Aristotle says that in kingdom system virtues can be achieved more easily and king is more virtue than other people, he does not ignore that king is person that even by his virtues can be corrupted while people will not be easily corrupted like paramount water. Interestingly, statements by Imam Khomeini on the fact that majority would not make a mistake has many similarities with paramount water in the words of Aristotle. Aristotle asserts that when people gather, they will achieve a right conception of affairs and it will be benefit for the city when they are mixed with the best people (Humes , 1991, 169)like unclean food which is more useful than a clean food when it is mixed 
with clean one. in contrary, when someone is separated from others, his/her judgment is not counted. Therefore, because of the high status of Constitution Law formulators headed by Imam Khomeini, the phenomenon of councils in Iran after Islamic Revolution is not a subject which can be discounted to simply theoretical fields and individualistic consultancies due to the needs of rulers; rather, it is a phenomenon that has put councils as one of the pillars of I. R. of Iran regime by intervening the people in decision makings, monitoring and accountability of officials. It is seen as an excellent status in decision making, running and monitoring the affairs of the country and, by this way, I. R. of Iran regime has found a democratic nature.

\section{Decentralization}

It seems that administrative decentralization can be studied in two aspects: on the one hand, by decentralization along with de-crowding, state mitigates the load of its administrative responsibilities and, on the other hand, decentralization is seen as a factor to create another type of citizens' contribution in their affairs titled "local contribution" as a supplementary to political contribution. In this aspect, local government divides the power and creates an alternative resource for the authority of central government ( Leigh, 2000, 7) . In his well-known book "selective administration", John Stuart Mill has clarified local government concept well so that peoples selected organs in two local and regional levels should monitor local officers. To clarify the theoretical foundations of decentralization and its role in administrative laws, one should initially explore represented justifications and then recognize its axels.

\section{Justification on the Necessity of Decentralization}

To get familiar with decentralization and its theoretical basics, analyzing its scientific and practical justifications is inevitable. These justifications can be categorized in two "classic" and "modern" justifications.

\section{a. Decentralization classic justification}

The classic reasons to justify decentralization by which citizens see themselves closer to the center of decision making especially on direct urban life involves two important aspects.

First, in this pattern, citizens intervene in a part of actions by the Executive Power. Second, decentralized pattern is a tool to monitor elected political representatives and employees so that they can always modify and evaluate their performance in formulating and executing public policies. In such case, decentralization will be a guarantee for the best measurement of public needs in local level and finding proper response which would lead into administrative process improvement especially in providing public services. As a result, decentralization would pave the way for the best supervision on public services since public service users would monitor on providing these services indirectly ( Ghalibaf, 2010, 114).

\section{b. Decentralization modern justification}

Irrespective of classic reasons to justify decentralization, one can also find today modern ones.

First, decentralization has paramount importance in clarifying local conditions for development. In current conditions, development relates to many factors by which economic activity cannot be conducted only in a certain region; rather, we need to divide them based on the conditions of each region. On this basis, decentralization can determine proper organization for development (Ibid, 118). As a result, the form and nature of production will be defined by local conditions and a direct link will be established between local consumers and manufacturers. Obviously, economic development requires more investments for which macro companies have no problems and these are minor companies which face with difficulties. Local modern organizing and administrative and, consequently, economic decentralization gives minor companies the opportunity to achieve strategic financial resources ( Shams, 2011, 28).

\section{Local Democracies and Councils}

It is useless to talk about democracy without recognizing collective contribution right of all citizens. Government's maximum intervention in the management of local affairs is incompatible with people's will governance principle, the right of determining the fate and the principles of the Constitution Law. Hence, one should say that councils can lead democracies from a minimum to a maximum concept. Democracy is a political system which provides citizens with legal, logic and regular opportunities to change administrative officials. Also, one can say that democracy is the "manifestation of people's will in management and governance" and article 2 of French Constitution Law (1958) and the opinion of Abraham Lincoln on democracy say "governance over people, on behalf of people and by people ( Matt Leighninger, 2014). Likewise, one can say that local democracy would have the same general conditions and features of democracy. In the meantime, councils have plural and divers management by which they are closer to democracy ideals and would lead democracy from a 
minimum to a maximum concept (State of Local Democracy, 2013) .

In countries like Iran the government is integrated, the scope of local democracy is limited to granted competencies from central government. In fact, the basis of local democracy and councils is decentralization in assigning a part of authorities of central powers to local entities. Local entities cannot use democratic tools beyond competencies granted to them by Parliament. Public contribution, identification, ensuring personal and collective liberties, law orientation and equity are all radical foundations of democratic administration in both local and national types (Modir Shanehchai, 2000, 84).

Collective contribution is seen as a predicament emphasized more in local democracy. Collective contribution is the most obvious symbol of democratic mechanisms. It is useless to talk about democracy without recognizing collective contribution right of all citizens. The role of councils is too important in fostering the feeling of contribution, democracy assignment and re-integration (Decentralization, 2009).

In this vein, another issue that addressing it can clarify the scope of council's competency is the point that in integrated countries with single political management, councils are one of the forms of decentralization. The foundation of decentralization is to grant independence and competency to local units so that they can make decisions by considering local conditions. The importance of councils' independence is that in the framework of sovereignty, one can have state's maximum intervention in managing local affairs including selection of mayors incompatible with people's faith. Enjoying administrative and financial independence and determining norms are, inter alia, the conditions of decentralization and lack of granting such independence would destroy the concept of decentralization . Local government is a layer of governmental officials to which citizens expect to resolve their social problems immediately. Likewise, it is a level of democracy in which citizens have the opportunity to participate in selected decisions for total society in the most active and direct way ${ }^{1}$. Local governments focus on smaller issues and provide more perspective to use democracy directly. It is direct democracy seen by almost all citizens in all issues. In representative democracy, citizens are among candidates or political parties for making valid decisions for all society ${ }^{2}$.

\section{Conclusion}

In contrary to non-integrated states, in integrated states one cannot talk about political management plurality. In fact, when we recall financial, administrative and norming independence in integrated countries, we do not mean breaking the ground of political power unity. Defining elective proficiencies should be so that the executors cannot deprive citizens from the right of determining their fate. In the format of administrative decentralization system, some norming competencies should be gradually assigned to Islamic Councils. Considering principle 100 of Iranian Constitution Law, one can say that this principle has not recognized no independence for councils in running the local affairs of villages, counties, cities, townships or provinces and the maximum role recognized by the Constitution Law for councils is to "cooperate with state to put forward the plans" and to "monitor on running local affairs." In fact, despite of executing the law of councils, local management is still in hands of central entities so the mechanisms to monitor councils is ambiguous and one can doubt that councils can monitor governmental official and prevent the execution of states' decisions.

In fact, prediction of monitoring mechanisms and ensuring the execution without deriving from legal tasks cannot be problematic legal; what may be misused by establishing powers is the concept of "deviation" and "legal tasks".

Therefore, determining the legal scope by central powers should be in a manner that it does not damage the main aim of administrative decentralization (décentralisation administrative). First, the main aim of the system is to decentralize granting financial, administrative and subjective independence to local councils. Second, the concept of "deviation" lacks a clear legal definition and, to the same reason, it can be used as an excuse to threat and constraint Islamic councils. Drawing the scope of councils' legal tasks by central powers should not damage decentralization principle (granting a part of independence to local councils). Anyhow, councils' monitoring right can guide executive organs toward right legal channels.

\section{References}

AlKajbaf, H. (2008). Islamic Councils in Iranian Laws. Tehran, Payam Pooya Publications.

Bashirieh, H. (2008). transition to democracy. Negah Moaser Publications.

Council and democracy. (2014). http://www.norfolk.gov.uk/Council_and_Democracy/index.htm

\footnotetext{
${ }^{1}$ Democracy at the Local Level the International Idea Handbook on Participation, Representation

${ }^{2}$ Leadership for Local Democracy, Local Democracy Assessment Guide, 2013
} 
Danesh Khsohbu, Y. (1970). running the affairs of local organizations. Tehran, Danesh.

Eivazi, M. R. (2006). political contribution in I. r. of Iran. Tehran. Islamic Revolution Documents Publication Center.

Frederic, K. (2010). evolution of urban democracy. Tehran, Azarakhsh Publications.

Ghalibaf, M. B. (2010). local administration or the strategy of political power judicial distribution in Iran. Tehran, Amir Kabir Publications.

Humes, S. (1991). local governance and national power.

Khatami, S. M. (2009). parties and councils. Tehran, Tarh-e-No Publications.

Leigh, I. (2000). Law, Politics and Local Democracy. New York, Oxford. http://dx.doi.org/10.1093/acprof:oso/9780198256984.001.0001

Matt Leighninger. (2014). Planning for Stronger Local Democracy.

Modir Shanehchai, M. (2000). decentralization and underdevelopment in contemporary Iran. Tehran, Rasa Cultural Services Publications.

Shams, A. H. (2011). local governance (from de-crowding to decentralization). Tehran, Presidency, Public Management Training Center Publications.

Tabatabei Motameni, M. (2002). administrative laws. SAMT Publications.

Zahedi, A. (2006). questions and answers on Islamic Council Laws. Tehran, Jangal Publications.

\section{Copyrights}

Copyright for this article is retained by the author(s), with first publication rights granted to the journal.

This is an open-access article distributed under the terms and conditions of the Creative Commons Attribution license (http://creativecommons.org/licenses/by/4.0/). 